\title{
The Impact of the COVID-19 Pandemic on Mathematics E-learning in Its Provincial and Migratory Schools in the Kingdom of Saudi Arabia (Al-Muzahmiyya Governorate as A Model)
}

\author{
Ghadah Salem.S. ALNaimi \\ E-mail: gadasssn2@gmail.com
}

\begin{abstract}
:
The current study aimed to identify the impact of the COVID-19 pandemic on mathematics e-learning in its provincial and migratory schools in the Kingdom of Saudi Arabia (Al-Muzahmiyya Governorate as a model). The researcher used the descriptive analytical method. The study sample consisted of (58) female mathematics teachers in Al-Muzahimiyah Governorate in government schools in the three educational stages (primary, intermediate and secondary), and they whose responded to participate in the study tool. The researcher used the questionnaire as a tool for data collection. The study finding that the lockdown related to the COVID-19 caused negative affect to mathematics teaching at the schools of Al-Muzahimiyah Governorate, and the Madrasati platform had a very large role in improving student learning outcomes, and the results of the study also showed that the electronic educational supervision has a very large role in supporting math teachers in Muzahimiyah schools, and there are many challenges that faced the activation of Madrasati platform, including the low internet services, especially during COVID-19 pandemic, due to the unprecedented overload on the network, and teachers face more workload and stress to provide acceptable quality of education to students, lack of preparation and technical competencies and professionalism for teachers and students to use the Madrasati platform in particular and e-learning in general. The study presented a set of strategies to overcome these challenges, and the study recommended the expansion of e-training programs and activities for teachers and students to use and employ the tools of the Madrasati platform in teaching mathematics. Financially supporting and motivating the teachers to overcome the problem of the increasing workload as a result of practicing digital learning activities and the teachers staying for long periods on the Internet. Increase the electronic educational supervision programs and activities to overcome the problems that teachers face in employing the tools of the Madrasati platform in teaching mathematics.
\end{abstract}

Keywords: COVID-19 pandemic - mathematics education - e-learning - educational platforms - Madrasati platform - electronic educational supervision - Saudi Arabia.

DOI: $10.7176 / \mathrm{JEP} / 12-30-03$

Publication date:October $31^{\text {st }} 2021$

\section{Introduction}

The rapid spread of the new Corona pandemic (COVID-19) led to the disruption of all aspects of life, especially schools, which was completely paralyzed, especially in the first six months of the pandemic's spread as a result of fear and anxiety about the speed of spread and the lack of knowledge of treatment protocols and how to control the virus, so many countries of the world resorted to lockdown of all life activities and gatherings, and the closure of educational institutions is considered one of the most important preventive measures.

At this critical stage of history all over the world, e-learning seemed to be the magic solution to the continuation of the education process. Countries varied in their readiness to use e-learning techniques efficiently and other countries also tried to rehabilitate their technological infrastructure to benefit from them in providing their educational services, which have become dependent on technology in an essential way (Rieley, 2020).

COVID-19 has put educational institutions in a great challenge to meet the requirements of quality education, and the sudden, rapid and forced shift from traditional learning (face-to-face education) to e-learning with its various technologies has increased this challenge for teachers, administrators, students, parents and decision makers to deal quickly and acquire skills necessary for the use of technology in education and overcoming the obstacles facing its use, whether in the lack of material capabilities or Internet connection points and access to it in remote places (Mulenga \& Marban, 2020).

There is no doubt that COVID-19 has caused chaos as a result of this sudden transformation of the education system in many countries, especially as a result of not knowing when the virus will end and the repeated waves of the virus, which cause an increase in infection rates and frequent lockdown as well. Governments should overcome all obstacles facing the application of e-learning to sustain their educational programs, especially with the exposure of technological infrastructure to extraordinary use as a result of pressure from users in huge numbers at the same time (Daniel, 2020), in addition, many teachers did not have sufficient willingness to engage in e-learning, and the disruption in scheduling, the quality of teaching, the processes of adaptation to e-learning, and the confidence in the e-learning possibilities that many have long questioned before the outbreak of the epidemic (Song et. al, 2020). 
Favale et al. (2020) indicated that the problems that followed the sudden shift from traditional education to e-learning had affected students' acceptance of and adaptation to e-learning, especially with students facing technical difficulties related to slow Internet, lack of direct communication between teacher and students, and lack of quality of e-learning tools and content, which led to increased levels of fear and anxiety among students, and negatively affected their concentration and levels of academic achievement.

Dorn et al. (2020) referred that many countries of the world have fallen into a bad experience as a result of poor infrastructure, technology or human infrastructure that efficiently deals with e-learning techniques during the complete lockdown caused by COVID-19. This experience has proven the importance of and the effectiveness of e-learning not only as an educational alternative, but as an integrated educational system.

Despite recognizing the importance and benefits of e-learning such as ensuring the sustainability of education (Akinbadewa \& Sofowora, 2020; Seage \& Türegün, 2020), providing lifelong learning (Alharthi, 2020) and lowering education costs (Al-Husban, 2020), although the learner and the teacher are in different places but there are some limitations in terms of methods, schedule and time (Weinhandl et al., 2020). In addition, there are many factors such as lack of infrastructure (software, hardware etc.), economic reasons, problem of technical personnel, lack of awareness of society and especially students in this regard, and regional differences (Rural vs. Urban) in the level of use of information technologies. They are seen as obstacles to e-learning and also distance education.

Several studies have been conducted to identify the perceptions of teachers and students of the problems they face during the implementation of e-learning programs and the use of its tools during the COVID-19 pandemic, including the study of (Arora \& Srinivasan, 2020) which was conducted on 341 teachers in Ghaziabad in India, with the aim of examining the adoption rate and benefits and the challenges of e-learning, and the findings of the study showed the presence of positive attitudes among teachers towards e-learning. While the findings of (Lall \& Singh, 2020) study showed a great willingness among students to use e-learning, in addition to the presence of positive attitudes towards it, because e-learning provides great flexibility among students. Also the (Xie and Yang, 2020) study reviewed students' experiences of studying at home during the epidemic and provided suggestions and measures for students to study alone and study independently during the epidemic.

The studies of (Basilaia \& Kvavadze, 2020; Zhao, 2020) agreed that online education has many benefits during the pandemic, but it also includes other problems that may reduce these benefits and may lead to confusion and frustration, such as the irregularity of the Internet as a result of the large increase numbers of users during the pandemic, and the lack of maintenance services as a result of closing shops and maintenance centers, in addition to many problems related to the distraction of students as a result of spending large times on social networking sites when teachers are not online, in addition to the lack of time management, low motivation, and the low of parents' conviction of the benefits of e-learning as students can easily obtain answers by searching the Internet or helping parents with homework, all of this reduces confidence in the ability of the Internet to provide quality education, despite the recognition that it is the most effective tool in the time of the pandemic.

The experiences of e-learning during the COVID-19 pandemic may differ, according to the experiences of previous practice. In some countries that were characterized by the use of e-learning before the pandemic, they showed great success in applying e-learning tools at the time of the pandemic, and this was approved by (Ferdig et al., 2020), while the study of (Alqahtani \& Rajkhan, 2020) confirmed that there are many problems that have encountered the sudden shift from traditional education to e-learning as a result of the lack of qualification of teachers, the lack of their technical skills, the lack of planning experience and its strategies for e-learning, in addition to the negative perceptions of students.

Basilaia \& Kvavadze, (2020) stressed the importance of training for teachers and students together in overcoming technical problems and ensuring the smooth transition of e-learning, and achieve success and making it more effective. This is what was actually done in their study, in which they used Google Classroom as a tool in the teaching and learning process, and used Google Meet to hold the conference as an alternative to meeting face to face, which achieved great success, that appeared in the improvement of student outcomes in the level of performance and teacher satisfaction with the e-learning experience during the COVID-19 pandemic.

According to Zahra et al, (2020), poor access to the Internet, especially in remote areas where there is a weakness in the Internet, can be overcome through the use of teacher videos recorded, which requires the availability of a set of standards, including sound and image quality, and not exceeding 10 minutes, and it is preferable to put a readable text with video and video improvement periodically in addition to the need to hold tests after each video or topic to ensure the students' positivity. Herliandry et al., (2020) stressed the need not to focus in judging on urban areas only, but should take into account rural areas that face more obstacles when providing e-learning services, especially during the COVID-19 epidemic.

The study of Al-Senussi and Al-Ghamdi (2021) indicated the effectiveness of the Madrasati platform in providing upper-grade students in the primary stage with oral expression skills. The study indicated the importance of the Saudi Madrasati platform in increasing student interaction and overcoming the problems they faced in traditional education. While Al Ibrahim's study (2020) referred to the obstacles of e-learning during the COVID19 pandemic, which are the lack of training of the administrative and teaching human element, technical obstacles, 
whether infrastructure or technological skills, in addition to obstacles related to students, lack of equipment and students' skills, and lack of time management.

The Najmuddin study (2021), which aimed to identify the reality of using the Madrasati platform during of the COVID-19 pandemic from the perspectives of social studies teachers in Jeddah. The study findings indicated the reality of using the platform from perspectives of the study sample is the effectiveness of the platform in teaching and learning, and the teachers reported that it violated expectations and proved its effectiveness. The study also indicated that the Ministry of education provided continuous technical support to ensure the progress of the educational process on the Madrasati platform, and the teachers commented on the positivity of the platform and that it helps female teachers to develop the skill of using technology among female teachers. The platform also contributed to the development of female teachers' self-learning skill through (YouTube, blogs). As for the negatives aspects, the teachers indicated that they had to re-create some assignments because they did not appear to the students. Changing the places where the assignment appears distracts the students.

Al-Harbi study (2021) indicated the importance of electronic educational supervision during the COVID-19 pandemic, as electronic supervision allows sharing some roles with the school leaders, and the quality of e-learning is monitored effectively by educational supervisors, but the study indicated a lack of training courses for teachers by educational supervision to improve the quality of e-learning.

The study of Al-Otaibi (2020) aimed to identify the reality of the employment of electronic platforms and their role in developing the academic achievement of mathematics among second-grade students in the middle school from the perspectives of mathematics teachers, and to take the Saudi Shams Network as a model, and the study sample consisted of all the mathematics teachers in the Shams electronic platform, who numbered 550 male and female teachers, and a stratified random sample of 197 male and female teachers was selected from the target population, and one of the most important results of the study was that mathematics teachers have the dimensions of employing electronic platforms in the Shams Network, which are (ease of use, easy to remember, efficiency, satisfaction, and avoiding errors), and that one of the most important reasons for the low level of academic achievement in mathematics for second-grade intermediate students in the Kingdom of Saudi Arabia is the lack of practical training for mathematics teachers on how to deal with the curriculum, in addition to the ease of using the Shams platform, and satisfaction with the use of the platform by teachers does not affect the development of the academic achievement in mathematics for second-grade intermediate students. The study recommended: The need to expand the use of e-learning platforms in general, and Shams platform in specific, in light of its efficiency and teachers' satisfaction with its use, in addition to the intensification of programs and practical training for mathematics teachers by teaching experts to gain sufficient experience qualified to teach students, and the establishment of communication networks between school libraries in different regions, and between teachers and students to transfer and exchange of knowledge of developed and modern programs for electronic platforms.

The use of technology in teaching has varied in developed and developing countries, as well as in rural and urban areas. For developed countries, the use of technology in teaching is nothing new because they have applied it for decades, while most developing countries are still fighting even in traditional classrooms in real time or socalled face-to-face education. This also applies to the countryside and cities, where schools in cities have a high quality in terms of technological infrastructure and training programs that are higher than villages, and this is what made many village teachers admit that they are not ready to use technology and do not even know how to use it, as some schools still lack facilities necessary to support the use of technology, and areas of abandonment do not have access to the Internet, in addition to the fact that parents are not convinced of the feasibility of using technology or trust in its educational outcomes (Onojah, 2020).

Therefore, the current study aimed to know the impact of the Covid-19 pandemic on electronic mathematics education in the urban and rural schools in the Kingdom of Saudi Arabia (Al-Muzahimiyah governorate as a model).

\section{Study methodology:}

In the Kingdom of Saudi Arabia, the Ministry of Education announced the "Madrasati" platform for students in general education, as an interactive educational alternative for distance education during the first seven weeks of the first semester. The platform provides many educational services, enriching electronic digital content, and various educational activities, which contribute to the continuation of the educational process without interruption, and achieve safety for male and female students during the COVID-19 pandemic; which adopted the slogan "Back to school without risks", as it is a return to education that transcends the lockdown policies as a result of the spread of the COVID-19. The digital platform contains a package of educational tools that support the planning and implementation of the educational process through virtual classes and meetings, in addition to assignments, electronic tests, discussion forums, and electronic questionnaires, as well as various educational resources (visual and cartoon videos - augmented reality - 3D resources - educational stories and books), e-mail provision, and Microsoft Office 365 programs. The platform provides various and renewable channels for effective communication between the beneficiaries of students and their parents, teachers, school leaders and supervisors. 
It also allows adding books and courses for all levels of public education, various educational and interactive paths, and a bank of more than 100,000 electronic refereed questions for all academic courses, in addition to digital platforms that include more than 45 thousand diverse educational digital content, between visual, electronic and games; More than 450,000 online lesson plans with the participation of male and female teachers. The Madrasati platform provides educational resources through which to learn English for all, and a mathematics club. It also enables students to view and learn traffic safety, free learning, learning programming and other motivating learning resources for students, teachers and parents. It also provides electronic questionnaires to measure performance, analyzes results and statistical reports, and demonstrates level of discipline and learning progress. (schools.madrasati.sa, 2021)

The researcher benefited from the features and capabilities of the Madrasati platform in conducting training and electronic educational supervision for mathematics teachers in Al-Muzahimiyah Governorate. The training and supervisory meetings through the use of virtual classes at the platform included developing the skills and competencies of mathematics teachers in the technical aspects and using the platform to provide mathematics lessons to students. Training and supervision related to the specialized academic aspects of mathematics. Through the Madrasati platform tools, the researcher was keen on the sustainability of the electronic support and supervision processes through the learning community tools offered by the platform, which provide continuous communication and interaction between the researcher, as an educational supervisor specializing in mathematics, and mathematics teachers in Al-Muzahimiyah Governorate, which focused on the participation of female students in e-learning activities and events, and applying the best educational practices using electronic knowledge sources and modern technologies in the processes of teaching mathematics.

The activation of the Madrasati platform has faced many challenges, including the lack of expertise and skills of the technical teachers, the lack of students' skills in using the tools of the Madrasati platform, in addition to the presence of anxiety and tension between the teachers and students also as a result of the interruption of the Internet or low Internet speed in some places, especially rural areas, in addition to that the teachers and the students did not have the full knowledge of using math symbols via the platform or in the virtual classroom, and the researcher worked to overcome many of these problems through training and electronic supervision, and some of them need strengthening the technological infrastructure.

\section{Population and Sample}

The study population consisted of all female mathematics teachers in Al-Muzahimiyah Governorate in government schools, and their number was about (83) female teachers during the academic year 1441/1442 AH. The study sample consisted of (58) female mathematics teachers in Al-Muzahimiyah Governorate in government schools in the three primary, intermediate and secondary educational stages, and they were whom responded to participation on the study tool and their questionnaires were fully filled out. Table (1) shows the distribution of study sample members according to the variables (educational stage - school location - educational qualification - years of experience - using e-learning in teaching mathematics before the Covid-19 pandemic - getting training programs in the use of e-learning in teaching mathematics before the Covid-19 pandemic).

Table (1) Distribution of study sample members according to study variables

\begin{tabular}{|c|c|c|c|}
\hline Variable & Categories & $\mathrm{N}$ & Percentage \\
\hline \multirow{4}{*}{ Educational Stage } & Primary School & 40 & $68.97 \%$ \\
\hline & Middle School & 11 & $18.97 \%$ \\
\hline & High School & 7 & $12.07 \%$ \\
\hline & Total & 58 & $100.00 \%$ \\
\hline \multirow{3}{*}{ School Location } & Inside the province & 43 & $74.14 \%$ \\
\hline & Outside the province (immigration) & 15 & $25.86 \%$ \\
\hline & Total & 58 & $100.00 \%$ \\
\hline \multirow{3}{*}{ Qualification } & Diploma & 14 & $24.14 \%$ \\
\hline & $\mathrm{BA}$ & 44 & $75.86 \%$ \\
\hline & Total & 58 & $100.00 \%$ \\
\hline \multirow{5}{*}{ Years of Experience } & Less than 5 years & 3 & $5.17 \%$ \\
\hline & $5-10$ years old & 14 & $24.14 \%$ \\
\hline & $10-20$ years old & 27 & $46.55 \%$ \\
\hline & More than 20 years & 14 & $24.14 \%$ \\
\hline & Total & 58 & $100.00 \%$ \\
\hline \multirow{3}{*}{$\begin{array}{l}\text { Use e-learning in mathematic teaching } \\
\text { before the COVID-19 pandemic }\end{array}$} & Yes & 16 & $27.59 \%$ \\
\hline & No & 42 & $72.41 \%$ \\
\hline & Total & 58 & $100.00 \%$ \\
\hline
\end{tabular}




\begin{tabular}{c|c|c|c}
\hline Variable & Categories & $\mathrm{N}$ & Percentage \\
\hline Obtaining training courses to use e- \\
learning in teaching mathematics before & Yes & 16 & $27.59 \%$ \\
\cline { 2 - 4 } the COVID-19 pandemic & No & 42 & $72.41 \%$ \\
\cline { 2 - 4 } & Total & 58 & $100.00 \%$ \\
\hline
\end{tabular}

\section{Study design:}

This study used the descriptive approach, which means determining the current state of the subject of the study according to its target variables. This approach is suitable to answer the questions of the study to know the impact of the Covid-19 pandemic on e-mathematics education in the urban and rural schools in the Kingdom of Saudi Arabia (Al-Muzahimiyah governorate as a model).

\section{Study tool:}

The researcher used the questionnaire as a tool for data collection because of its features that fit the nature of the current study and contribute to achieving its objectives. The questionnaire consisted of two parts; The first includes the basic variables (educational stage - school location - educational qualification - years of experience - Use elearning in mathematic teaching before the COVID-19 pandemic - Obtaining training courses to use e-learning in teaching mathematics before the COVID-19 pandemic), while the second part consists of (5) axes containing (42) statements identifying the impact of the Covid-19 pandemic on e-mathematics education in the urban and rural schools in the Kingdom of Saudi Arabia (Al-Muzahimiyah governorate as a model). Table (2) shows the distribution of statements on the main axes.

Table (2) the distribution of statements on the main axes

\begin{tabular}{c|c|c|c}
\hline $\mathrm{N}$ & Axes & $\begin{array}{c}\text { Number of } \\
\text { statements }\end{array}$ & $\begin{array}{c}\text { statements } \\
\text { numbers }\end{array}$ \\
\hline 1 & $\begin{array}{c}\text { The impact of the study suspension related to the Covid-19 } \\
\text { pandemic on mathematics teaching }\end{array}$ & 9 & $1-9$ \\
\hline 2 & $\begin{array}{c}\text { The role of Madrasati platform in improving student learning } \\
\text { outcomes }\end{array}$ & 8 & $10-17$ \\
\hline 3 & $\begin{array}{c}\text { The role of electronic educational supervision in supporting } \\
\text { mathematics teachers in Al-Muzahimiyah schools }\end{array}$ & 9 & $18-26$ \\
\hline 4 & Challenges faced activating Madrasati platform & 8 & $27-34$ \\
\hline 5 & Reducing the challenges of activating Madrasati platform & 8 & $35-42$ \\
\hline
\end{tabular}

\section{Questionnaire validity:}

Face validity:

The face validity of the questionnaire was verified by viewing it in its initial form that included (42) phrases distributed over 5 axes on several arbitrators with experience and specialization in Saudi universities. The researcher asked the distinguished arbitrators to express their observations about the extent to which each phrase is related to its axis, and the soundness of the linguistic formulation of each phrase, and its relevance to the characteristics of the sample, deleting similar or inappropriate statements that do not serve the objectives of the study, and adding axes or statements that they deem appropriate to serve the objectives of the study. The arbitrators expressed their opinions about the tool by modifying some phrases, reformulating them and replacing other appropriate ones. After the arbitration, the tool appeared in its final form, consisting of 5 axes and 42 phrases.

\section{Content validity:}

To check the content validity of the questionnaire; The researcher applied it to an pilot study sample of (15) teachers not of basic research sample, and the Pearson correlation coefficient was calculated for each phrase and the axis to which it belongs, and for each axis of the tool and the tool as a whole. The correlation coefficients for the questionnaire phrases ranged between $(0.581-0.907)$, which are high correlation coefficients, indicating the content validity of the questionnaire.

Questionnaire reliability:

To check the reliability of the questionnaire; Cronbach's Alpha coefficient was calculated for each axes, and for all axes, after processing the pilot sample data. 
Table (3) Cronbach's Alpha coefficients of reliability of the questionnaire

\begin{tabular}{|c|c|c|c|}
\hline $\mathrm{N}$ & Axes & $\begin{array}{l}\text { Number of } \\
\text { phrases }\end{array}$ & $\begin{array}{l}\text { Cronbach's alpha } \\
\text { coefficient }\end{array}$ \\
\hline 1 & $\begin{array}{l}\text { The impact of the study suspension related to the Covid-19 } \\
\text { pandemic on mathematics teaching }\end{array}$ & 9 & 0.947 \\
\hline 2 & $\begin{array}{l}\text { The role of Madrasati platform in improving student learning } \\
\text { outcomes }\end{array}$ & 8 & 0.896 \\
\hline 3 & $\begin{array}{l}\text { The role of electronic educational supervision in supporting } \\
\text { mathematics teachers in Al-Muzahimiyah schools }\end{array}$ & 9 & 0.869 \\
\hline 4 & Challenges faced activating Madrasati platform & 8 & 0.867 \\
\hline 5 & Reducing the challenges of activating Madrasati platform & 8 & 0.899 \\
\hline & Total & 42 & 0.905 \\
\hline
\end{tabular}

The previous table indicated that the study tool has high reliability coefficients that allow it to be used in the current study and applied to the study sample.

\section{Results and Discussion:}

To answer the first question, "What is the impact of the study suspension related to the Covid-19 pandemic on mathematics teaching?" In order to answer this question, the arithmetic averages and standard deviations of the responses of the study sample to the statements of questionnaire that determine and monitor the impact of the study suspension related to the COVID-19 pandemic on the teaching of mathematics were used, and they are arranged in descending order according to the arithmetic averages as shown in the following table:

Table (4) the impact of the study suspension related to the Covid-19 pandemic on mathematics teaching

\begin{tabular}{c|l|c|c|c|c}
\hline $\mathrm{N}$ & \multicolumn{1}{c|}{ Phrase } & $\begin{array}{c}\text { Arithmetic } \\
\text { Mean }\end{array}$ & $\begin{array}{c}\text { Standard } \\
\text { Deviation }\end{array}$ & Ranking & $\begin{array}{c}\text { Availability } \\
\text { Score }\end{array}$ \\
\hline 1 & $\begin{array}{l}\text { The suspension led to a disturbance in the } \\
\text { distribution of mathematics curriculum }\end{array}$ & 3.48 & 1.217 & 4 & High \\
\hline 2 & $\begin{array}{l}\text { The suspension led to the non-completion of } \\
\text { teaching mathematics curriculum }\end{array}$ & 3.10 & 1.507 & 9 & Medium \\
\hline 3 & $\begin{array}{l}\text { The suspension led to the closure of schools and } \\
\text { the cessation of teaching }\end{array}$ & 3.22 & 1.623 & 7 & Medium \\
\hline 4 & $\begin{array}{l}\text { The suspension made it difficult for students } \\
\text { follow up in learning mathematics }\end{array}$ & 3.41 & 1.427 & 6 & High \\
\hline 5 & $\begin{array}{l}\text { The suspension led to a decrease in personal } \\
\text { stimulus and motivation to teach mathematics }\end{array}$ & 3.45 & 1.327 & 5 & High \\
\hline 6 & $\begin{array}{l}\text { The suspension led to a low level of students } \\
\text { performance in mathematics }\end{array}$ & 3.50 & 1.260 & 3 & High \\
\hline 7 & $\begin{array}{l}\text { The suspension led to the emergence of } \\
\text { educational losses among students in } \\
\text { mathematics }\end{array}$ & 3.88 & .993 & 1 & Medium \\
\hline 8 & $\begin{array}{l}\text { The suspension led to an increase in students' } \\
\text { negative attitudes towards mathematics }\end{array}$ & 3.16 & 1.197 & 8 & High \\
\hline 9 & $\begin{array}{l}\text { The suspension led to the lack of verification of } \\
\text { students' learning outcomes in mathematics }\end{array}$ & 3.66 & 1.305 & 2 & High \\
\hline
\end{tabular}

It is clear from table (4) that the arithmetic mean of the effect of the study suspension related to the COVID19 pandemic on mathematics teaching in Al-Muzahimiyah Governorate ranged between $(3.10-3.88)$, and that the total arithmetic mean of the effect of the study suspension associated with the COVID-19 pandemic on mathematics teaching amounted to (3.43), that is, that the suspension of studies related to the Covid-19 pandemic has highly affected the teaching of mathematics in the schools of Al-Muzahimiyah Governorate.

The researcher attributes this result to the significant impact of the study suspension related to the Covid-19 pandemic on the teaching of mathematics. The pandemic where the suspension of the study led to the suspension of teaching activities and low level of performance of the students, which caused a great educational loss, and this situation was further complicated by the presence of a disorder in the distribution of the mathematics curriculum to confront the problem and try to fit in with the pandemic and the disruption it caused in all aspects of life, including the teaching process. These results are consistent with the study (Daniel, 2020; Zhong, 2020; Toquero, 2020), which recognized that the suspension associated with the spread of the COVID-19 pandemic has negatively affected the educational process and has led to a partial suspension of teaching until the available possibilities of using technological techniques in teaching are activated. 
To answer the second question: "What is the role of the Madrasati platform in improving student learning outcomes?" In order to answer this question, the arithmetic averages and standard deviations of the responses of the study sample members to statements of questionnaire that define and monitor the role of the Madrasati platform in improving student learning outcomes were used, and they were arranged in descending order according to the arithmetic averages as shown in the following table:

Table (5) The role of the Madrasati platform in improving student learning outcomes

\begin{tabular}{|c|l|c|c|c|c|}
\hline $\mathrm{N}$ & \multicolumn{1}{|c|}{ Phrase } & $\begin{array}{c}\text { Arithmetic } \\
\text { Mean }\end{array}$ & $\begin{array}{c}\text { Standard } \\
\text { Deviation }\end{array}$ & Ranking & $\begin{array}{c}\text { Availability } \\
\text { Score }\end{array}$ \\
\hline 9 & $\begin{array}{l}\text { The platform contributed to the return to schools and } \\
\text { the continuity of the education process }\end{array}$ & 4.52 & .538 & 1 & Very High \\
\hline 10 & $\begin{array}{l}\text { The platform allowed teachers to provide enrichment } \\
\text { activities to expand the understanding of students }\end{array}$ & 4.48 & .599 & 2 & Very High \\
\hline 11 & $\begin{array}{l}\text { The platform contributed to enabling teachers to } \\
\text { have a variety of assessment methods (worksheets, } \\
\text { tests, assignments, research) }\end{array}$ & 4.41 & .726 & 4 & Very High \\
\hline 12 & $\begin{array}{l}\text { The platform provides digital mathematics content in } \\
\text { different formats (text, image, audio, video clips), } \\
\text { which increases educational attainment from the } \\
\text { traditional classroom. }\end{array}$ & 4.45 & .654 & 3 & Very High \\
\hline $\begin{array}{l}\text { The virtual classroom tools in the platform allowed } \\
\text { the interaction between the teacher and the students } \\
\text { to enhance the understanding of mathematics topics }\end{array}$ & 4.28 & .874 & 7 & Very High \\
\hline 14 & $\begin{array}{l}\text { The platform provided open source resources and } \\
\text { resources that are not available in the traditional } \\
\text { classroom }\end{array}$ & 4.36 & .667 & 6 & Very High \\
\hline 15 & $\begin{array}{l}\text { The platform provided the opportunity to build open } \\
\text { communities for teachers to exchange experiences } \\
\text { and skills }\end{array}$ & 4.40 & .724 & 5 & Very High \\
\hline $\begin{array}{l}\text { The platform contributed to the positivity and } \\
\text { activity of the students, which makes learning more } \\
\text { effective }\end{array}$ & 3.98 & 4.36 & .561 & & High \\
\hline
\end{tabular}

It is clear from table (5) that the arithmetic mean of the role of the Madrasati platform in improving student learning outcomes ranged between $(3.98$ - 4.52), and that the total arithmetic mean of the role of the Madrasati platform in improving student learning outcomes was (4.36), meaning that the Madrasati platform has a very large role in improving student learning outcomes.

The researcher attributes this findings to the great role played by the Madrasati platform in improving student learning outcomes, especially this platform returning students to study again, as the Madrasati platform has become the main platform for continuing study and teaching mathematics, where this platform has possessed many advantages that make it superior to the advantages of traditional teaching, as the platform allows activating digital content with its various advantages, especially multimedia, in addition to digital enrichment activities that enhance the learning process for students, expand the base of understanding and application of students, and provide many assessment methods that enhance the teachers' ability to measure students' learning outcomes and develop the necessary plans to improve students' learning outcomes. These findings are consistent with the study of (AlSenussi and Al-Ghamdi, 2021; Najm Al-Din, 2021), which confirmed the ability of the Madrasati platform to improve student performance and improve learning outcomes, as well as consistent with Al-Otaibi's study (2020) that confirmed the ability of electronic platforms to improve students' results in mathematics.

To answer the third question: "What is the role of electronic educational supervision in supporting mathematics teachers in Muzahimiyah schools?" In order to answer this question, the arithmetic means and standard deviations of the responses of the study sample to statements of questionnaire that define and monitor the role of electronic educational supervision in supporting mathematics teachers in Muzahimiyah schools were used, and they were arranged in descending order according to the arithmetic means as shown in the following table: 
Table (6) he role of electronic educational supervision in supporting mathematics teachers in Muzahimiyah schools

\begin{tabular}{|c|c|c|c|c|c|}
\hline $\mathrm{N}$ & Phrase & $\begin{array}{c}\text { Arithmetic } \\
\text { Mean }\end{array}$ & $\begin{array}{c}\text { Standard } \\
\text { Deviation }\end{array}$ & Ranking & $\begin{array}{c}\text { Availability } \\
\text { Score }\end{array}$ \\
\hline 17 & $\begin{array}{l}\text { Educational supervision determined the training } \\
\text { needs of mathematics teachers before starting work by } \\
\text { the platform. }\end{array}$ & 3.59 & 1.124 & 9 & High \\
\hline 18 & $\begin{array}{l}\text { Educational supervision has enhanced the role of } \\
\text { teachers at the platform by holding training programs } \\
\text { and workshops to develop their technical skills. }\end{array}$ & 4.02 & .908 & 8 & High \\
\hline 19 & $\begin{array}{l}\text { Educational supervision has enhanced the role of } \\
\text { teachers at the platform by holding training programs } \\
\text { and workshops to develop their electronic teaching } \\
\text { performance. }\end{array}$ & 4.19 & .826 & 6 & High \\
\hline 20 & $\begin{array}{l}\text { Teachers participated in the planning processes of e- } \\
\text { teaching through the platform. }\end{array}$ & 4.29 & .749 & 6 & Very High \\
\hline 21 & $\begin{array}{l}\text { The educational supervisor held a workshop for } \\
\text { teachers in addressing educational losses for female } \\
\text { students at all levels. }\end{array}$ & 4.59 & .593 & 4 & Very High \\
\hline 22 & $\begin{array}{l}\text { The educational supervisor monitors the quality of e- } \\
\text { learning and provides support to teachers in a timely } \\
\text { manner. }\end{array}$ & 4.69 & .503 & 1 & Very High \\
\hline 23 & $\begin{array}{l}\text { The educational supervisor helped to solve the } \\
\text { problems facing mathematics teachers while using the } \\
\text { Madrasati platform. }\end{array}$ & 4.55 & .680 & 5 & Very High \\
\hline 24 & $\begin{array}{l}\text { The educational supervisor held virtual meetings with } \\
\text { the teachers for continuous follow-up and } \\
\text { improvement of their teaching performance. }\end{array}$ & 4.69 & .467 & 2 & Very High \\
\hline 25 & $\begin{array}{l}\text { Providing feedback to teachers about their teaching } \\
\text { performance on the Madrasati platform. }\end{array}$ & 4.69 & .467 & 3 & Very High \\
\hline \multicolumn{2}{|r|}{ Uver } & 4.37 & .512 & & Very High \\
\hline
\end{tabular}

It is clear from table (6) that the arithmetic means of the role of electronic educational supervision in supporting mathematics teachers in Al-Muzahmiyah schools ranged between (3.59 - 4.69), and that the total arithmetic mean of the role of electronic educational supervision in supporting mathematics teachers in AlMuzahimiyah schools was (4.37), meaning that the electronic educational supervision has a large role in supporting mathematics teachers in Muzahimiyah schools.

The researcher attributes this findings to the great role played by electronic educational supervision in supporting mathematics teachers in Muzahimiyah schools by training teachers to use and employ the capabilities of the Madrasati platform in teaching mathematics and activating the tools offered by the platform to maximize the benefit from the potentials of e-learning in teaching mathematics, in addition to virtual meetings conducted by educational supervision in order to support and enhance the teaching skills of teachers, discuss the problems they face in e-teaching and provide appropriate solutions to these problems. This is in addition to the educational supervision following up the performance of the teachers, providing them with feedback and providing them with the appropriate support in the e-teaching process, whether planning, implementing or evaluating teaching. These findings are consistent with Al-Harbi's study (2021) who confirmed the importance of electronic educational supervision during the COVID-19 pandemic, as electronic supervision allows sharing some roles with the school leadership, and the quality of e-learning is effectively monitored by educational supervisors.

To answer the fourth question: "What are the challenges that faced the activating of Madrasati platform?" In order to answer this question, the arithmetic means and standard deviations of the responses of the study sample to statements of the questionnaire that identify and monitor the challenges faced in activating the Madrasati platform were used, and they were arranged in descending order according to the arithmetic meand as shown in the following table: 
Table (7): Challenges encountered in activating the Madrasati platform

\begin{tabular}{|c|c|c|c|c|c|}
\hline $\mathrm{N}$ & Phrase & $\begin{array}{l}\text { Arithmetic } \\
\text { Mean }\end{array}$ & $\begin{array}{c}\text { Standard } \\
\text { Deviation }\end{array}$ & Ranking & $\begin{array}{l}\text { Availability } \\
\text { Score }\end{array}$ \\
\hline 26 & $\begin{array}{l}\text { Feeling anxious and afraid of the sudden transition } \\
\text { from traditional education to e-learning }\end{array}$ & 3.72 & 1.073 & 6 & High \\
\hline 27 & $\begin{array}{l}\text { Low internet services, especially at the time of the } \\
\text { Corona pandemic, due to the unprecedented pressure } \\
\text { on the network }\end{array}$ & 4.22 & .773 & 1 & Very High \\
\hline 28 & $\begin{array}{l}\text { The lack of willingness and technical and } \\
\text { professional competencies for teachers to use the } \\
\text { Madrasati platform and e-learning in general }\end{array}$ & 3.48 & 1.064 & 7 & High \\
\hline 29 & $\begin{array}{l}\text { Lack of willingness and technical and professional } \\
\text { competencies for female students to use the } \\
\text { Madrasati platform and e-learning in general }\end{array}$ & 3.97 & .973 & 3 & High \\
\hline 30 & $\begin{array}{l}\text { Female students usually face technical problems that } \\
\text { are difficult to solve due to the lack of technical } \\
\text { support and negatively affect the courses teaching } \\
\text { progress. }\end{array}$ & 3.74 & 1.117 & 5 & High \\
\hline 31 & $\begin{array}{l}\text { It is difficult to manage the student's learning time as } \\
\text { a result of the increase in stimuli on the Internet and } \\
\text { the loss of time between social networking sites }\end{array}$ & 3.93 & 1.074 & 4 & High \\
\hline 32 & $\begin{array}{l}\text { Teachers face more workload and stress level to } \\
\text { provide education of acceptable quality to female } \\
\text { students }\end{array}$ & 4.22 & .937 & 2 & Very High \\
\hline 33 & $\begin{array}{l}\text { It is difficult to use math tools and symbols in } \\
\text { Madrasati platform }\end{array}$ & 3.29 & 1.257 & 8 & Medium \\
\hline & Overall Mean & 3.82 & .750 & & High \\
\hline
\end{tabular}

It is clear from table (7) that the arithmetic means of the challenges faced activating the Madrasati platform in the Muzhamiya schools ranged between (3.29 - 4.22), and that the total arithmetic mean of the challenges faced in activating Madrasati platform in the Muzhamiya schools was (3.82), meaning that there were high availability of challenges that encountered the activation of Madrasati platform in Muzahimiyah schools.

The researcher attributes this result to the fact that the closure process that accompanied the spread of the COVID-19 pandemic has led to an increase in demand on the Internet and the presence of very large stress on the network as a result of the population staying long time at home, which led to the decline in Internet services that were not planned for this unprecedented use on the network. Also, the migration areas (rural areas) already suffer from poor internet services before the pandemic, which has increased with the pandemic and the breakdown. This is in addition to the sudden shift from traditional education to e-learning, which has revealed the lack of psychological, technical and skillful readiness of teachers and students alike to learn through the Internet as a complete alternative to traditional learning. Also the lack of rapid technical support to treat problems of electronic teaching, low Internet speed or technology internal problems of Madrasati platform. These findings are consistent with the (Alqahtani \& Rajkhan, 2020) study that confirmed the existence of many problems that encountered the sudden shift from traditional education to e-learning as a result of the lack of qualification of teachers, the lack of their technical skills, the lack of planning experiences for e-teaching and its strategies, in addition to the negative perceptions of students. It also consistent with the (Dorn et al. 2020) study, which recognized that many countries of the world have fallen into a bad experience as a result of poor infrastructure, technology or human infrastructure that deals efficiently with e-learning techniques during the complete breakdown caused by COVID-19.

To answer the fifth question: "What are strategies to reduce the challenges that faced the activation of the Madrasati platform?" In order to answer this question, the arithmetic means and standard deviations of the responses of the study sample to statements of the questionnaire that identify and monitor strategies to reduce the challenges that faced the activation of the Madrasati platform were used, and they were arranged in descending order according to the arithmetic means as shown in the following table: 
Table (8) Strategies to reduce the challenges encountered in activating the Madrasati platform

\begin{tabular}{c|l|c|c|c|c}
\hline $\mathrm{N}$ & \multicolumn{1}{|c|}{ Phrase } & $\begin{array}{c}\text { Arithmetic } \\
\text { Mean }\end{array}$ & $\begin{array}{c}\text { Standard } \\
\text { Deviation }\end{array}$ & Ranking & $\begin{array}{c}\text { Availability } \\
\text { Score }\end{array}$ \\
\hline 34 & $\begin{array}{l}\text { Training teachers to use the platform well in } \\
\text { advance of starting work on it }\end{array}$ & 3.74 & 1.163 & 8 & High \\
\hline $\begin{array}{l}\text { Training the teachers to produce the educational } \\
\text { video and upload it on the platform to overcome the } \\
\text { problem of the lack of internet at the time of the } \\
\text { virtual class }\end{array}$ & 3.81 & 1.221 & 7 & High \\
\hline 36 & $\begin{array}{l}\text { Guiding teachers to make use of teachers' electronic } \\
\text { planning tools and materials }\end{array}$ & 4.17 & .752 & 2 & High \\
\hline 37 & $\begin{array}{l}\text { Providing feedback to the teachers about the } \\
\text { problems and situations they face while using the } \\
\text { platform }\end{array}$ & 4.16 & .745 & 3 & High \\
\hline 38 & $\begin{array}{l}\text { Support and enhance the ability of teachers to create } \\
\text { standardized electronic tests to overcome the factor } \\
\text { of students cheating in the test. }\end{array}$ & 4.21 & .695 & 1 & Very High \\
\hline 39 & $\begin{array}{l}\text { Activating the system of reports and indicators to } \\
\text { increase the motivation of students to positively } \\
\text { learn }\end{array}$ & 3.95 & .826 & 5 & High \\
\hline 40 & $\begin{array}{l}\text { Linking teaching to the platform with international } \\
\text { websites and electronic programs for teaching } \\
\text { mathematics }\end{array}$ & 3.95 & .847 & 6 & High \\
\hline 41 & $\begin{array}{l}\text { Enhancing the teachers ability to build indirect } \\
\text { digital content to overcome the problem of low } \\
\text { internet access }\end{array}$ & 4.09 & .708 & 4 & High \\
\hline \multicolumn{2}{|l|}{ Overall Mean } & 4.01 & .682 & & High \\
\hline
\end{tabular}

It is clear from table (8) that the arithmetic mean of the strategies to reduce the challenges that faced the activation of the Madrasati platform at Al-Muzahimiyah schools ranged between $(3.74-4.21)$ and the total arithmetic mean of the strategies to reduce the challenges that faced the activation of the Madrasati platform at AlMuzahmiyah schools was (4.01), this mean that the math teachers saw using these strategies will reduce the challenges that faced the activation of the Madrasati platform in the Muzahimiyah schools.

The researcher attributes this findings to the success of educational supervision in supporting and enhancing math teachers by training them to use the platform and employing its tools in the process of teaching mathematics, increasing the experience and developing the skills of teachers in designing electronic tests to reduce students' cheating and increasing teachers' ability to plan electronically for teaching in addition to benefiting from readymade plans which the platform provides for teachers to benefit from in the planning processes of teaching, continuous follow-up of teachers, providing them with feedback and participating in plans to improve the teaching performance of teachers or improve the performance of students in learning mathematics. These findings are consistent with the study of (Basilaia \& Kvavadze, 2020), which emphasized the importance of training for teachers and students together in overcoming technical problems, and the study of (Zahra et al, 2020), Which emphasized the possibility of overcoming poor access to the Internet, especially in rural areas where there is a weakness in the Internet, through the use of videos recorded by the teacher, and the study of (Al-Harbi, 2021), which emphasized the importance of the role of educational supervision in training math teachers to improve the quality of the educational process through the Madrasati platform.

To answer the sixth question: "Are there statistically significant differences in the responses of mathematics teachers in Al-Muzahmiyah Governorate schools to the axes of the questionnaire due to the variables (educational stage - school location - educational qualification - years of experience)?" To answer this question, the One-Way ANOVA test was used to indicate the differences between more than two independent groups to identify the differences in the responses of the study sample about the axes of the questionnaire according to the different variables (educational stage - years of experience) and the use of the " $t$ " test to indicate differences according to variables (school location - educational qualification). The following tables show these findings: 
First: Differences according to the educational stage variable:

Table (9) One-Way ANOVA test for the significance of the differences in the responses of the study sample according to the variable of the educational stage

\begin{tabular}{|c|c|c|c|c|c|c|c|}
\hline Axis & Variance & $\begin{array}{l}\text { Sum of } \\
\text { Squares }\end{array}$ & $\mathrm{df}$ & $\begin{array}{l}\text { Mean } \\
\text { Square }\end{array}$ & $\mathrm{F}$ & Sig. & $\begin{array}{c}\text { Sig. } \\
\text { meaning }\end{array}$ \\
\hline \multirow{3}{*}{$\begin{array}{l}\text { The impact of the study } \\
\text { suspension related to the Covid-19 } \\
\text { pandemic on mathematics } \\
\text { teaching }\end{array}$} & Between Groups & .241 & 2 & .120 & \multirow{3}{*}{.094} & \multirow{3}{*}{.911} & \multirow{3}{*}{$\begin{array}{l}\text { Not } \\
\text { significant }\end{array}$} \\
\hline & Within Groups & 70.486 & 55 & 1.282 & & & \\
\hline & Total & 70.727 & 57 & & & & \\
\hline \multirow{3}{*}{$\begin{array}{c}\text { The role of Madrasati platform in } \\
\text { improving student learning } \\
\text { outcomes }\end{array}$} & Between Groups & .069 & 2 & .034 & \multirow{3}{*}{.106} & \multirow{3}{*}{.900} & \multirow{3}{*}{$\begin{array}{l}\text { Not } \\
\text { significant }\end{array}$} \\
\hline & Within Groups & 17.840 & 55 & .324 & & & \\
\hline & Total & 17.909 & 57 & & & & \\
\hline \multirow{3}{*}{$\begin{array}{l}\text { The role of electronic educational } \\
\text { supervision in supporting } \\
\text { mathematics teachers in Al- } \\
\text { Muzahimiyah schools }\end{array}$} & Between Groups & .108 & 2 & .054 & \multirow{3}{*}{.199} & \multirow{3}{*}{.820} & \multirow{3}{*}{$\begin{array}{l}\text { Not } \\
\text { significant }\end{array}$} \\
\hline & Within Groups & 14.856 & 55 & .270 & & & \\
\hline & Total & 14.963 & 57 & & & & \\
\hline \multirow{3}{*}{$\begin{array}{c}\text { Challenges faced activating } \\
\text { Madrasati platform }\end{array}$} & Between Groups & .246 & 2 & .123 & \multirow{3}{*}{.212} & \multirow{3}{*}{.809} & \multirow{3}{*}{$\begin{array}{l}\text { Not } \\
\text { significant }\end{array}$} \\
\hline & Within Groups & 31.787 & 55 & .578 & & & \\
\hline & Total & 32.032 & 57 & & & & \\
\hline \multirow{3}{*}{$\begin{array}{l}\text { Reducing the challenges of } \\
\text { activating Madrasati platform }\end{array}$} & Between Groups & 2.345 & 2 & 1.173 & \multirow{3}{*}{2.667} & \multirow{3}{*}{.078} & \multirow{3}{*}{$\begin{array}{l}\text { Not } \\
\text { significant }\end{array}$} \\
\hline & Within Groups & 24.182 & 55 & .440 & & & \\
\hline & Total & 26.527 & 57 & & & & \\
\hline
\end{tabular}

It is clear from table (9) that the values of (F) in the five axes were respectively (0.094- $0.106-0.199-0.212$ - 2.667), which is a non-significant value at a significance level less than (0.05); Where the significance values were, respectively, $(0.911-0.900-0.820-0.809-0.078)$, which are not statistically significant, which means that there are no statistically significant differences in the responses of mathematics teachers in Al Muzahimiyah Governorate to the axes of the questionnaire according to the variable of the educational stage.

Second: Differences according to the variable years of experience:

Table (10) One-Way ANOVA test for the significance of the differences in the responses of the study sample according to the variable years of experience

\begin{tabular}{|c|c|c|c|c|c|c|c|}
\hline Axis & Variance & $\begin{array}{l}\text { Sum of } \\
\text { Squares }\end{array}$ & $\mathrm{df}$ & $\begin{array}{l}\text { Mean } \\
\text { Square }\end{array}$ & $\mathrm{F}$ & Sig. & $\begin{array}{c}\text { Sig. } \\
\text { meaning }\end{array}$ \\
\hline \multirow{3}{*}{$\begin{array}{c}\text { The impact of the study } \\
\text { suspension related to the Covid- } \\
19 \text { pandemic on mathematics } \\
\text { teaching }\end{array}$} & Between Groups & 5.122 & 3 & 1.707 & \multirow{3}{*}{1.405} & \multirow{3}{*}{.251} & \multirow{3}{*}{$\begin{array}{l}\text { Not } \\
\text { significant }\end{array}$} \\
\hline & Within Groups & 65.605 & 54 & 1.215 & & & \\
\hline & Total & 70.727 & 57 & & & & \\
\hline \multirow{3}{*}{$\begin{array}{c}\text { The role of Madrasati platform in } \\
\text { improving student learning } \\
\text { outcomes }\end{array}$} & Between Groups & 1.667 & 3 & .556 & \multirow{3}{*}{1.848} & \multirow{3}{*}{.149} & \multirow{3}{*}{$\begin{array}{l}\text { Not } \\
\text { significant }\end{array}$} \\
\hline & Within Groups & 16.241 & 54 & .301 & & & \\
\hline & Total & 17.909 & 57 & & & & \\
\hline \multirow{3}{*}{$\begin{array}{l}\text { The role of electronic educational } \\
\text { supervision in supporting } \\
\text { mathematics teachers in Al- } \\
\text { Muzahimiyah schools }\end{array}$} & Between Groups & 1.494 & 3 & .498 & \multirow{3}{*}{1.996} & \multirow{3}{*}{.126} & \multirow{3}{*}{$\begin{array}{l}\text { Not } \\
\text { significant }\end{array}$} \\
\hline & Within Groups & 13.470 & 54 & .249 & & & \\
\hline & Total & 14.963 & 57 & & & & \\
\hline \multirow{3}{*}{$\begin{array}{l}\text { Challenges faced activating } \\
\text { Madrasati platform }\end{array}$} & Between Groups & 4.179 & 3 & 1.393 & \multirow{3}{*}{2.701} & \multirow{3}{*}{.055} & \multirow{3}{*}{$\begin{array}{l}\text { Not } \\
\text { significant }\end{array}$} \\
\hline & Within Groups & 27.853 & 54 & .516 & & & \\
\hline & Total & 32.032 & 57 & & & & \\
\hline \multirow{3}{*}{$\begin{array}{l}\text { Reducing the challenges of } \\
\text { activating Madrasati platform }\end{array}$} & Between Groups & 1.203 & 3 & .401 & \multirow{3}{*}{.855} & \multirow{3}{*}{.470} & \multirow{3}{*}{$\begin{array}{l}\text { Not } \\
\text { significant }\end{array}$} \\
\hline & Within Groups & 25.324 & 54 & .469 & & & \\
\hline & Total & 26.527 & 57 & & & & \\
\hline
\end{tabular}

It is clear from table (10) that the values of $(\mathrm{F})$ in the five axes were respectively $(1.405-1.848-10.996$ $1.701-0.855)$, which is a non-significant value at a significance level less than $(0.05)$; Where the significance values were, respectively $(0.251-0.149-0.126-0.055-0.470)$, which are not statistically significant, which means that there are no statistically significant differences in the responses of mathematics teachers in $\mathrm{Al}$ Muzahimiyah Governorate to the questionnaire axes according to the variable years of experience. 
Third: Differences according to the variable of the school location:

Table (11) T-test for the significance of the differences in the responses of the study sample according to the variable of the school location

\begin{tabular}{|c|c|c|c|c|c|c|c|}
\hline Axis & $\begin{array}{c}\text { School } \\
\text { Location }\end{array}$ & $\mathrm{N}$ & $\begin{array}{l}\text { Arithmetic } \\
\text { Mean }\end{array}$ & $\begin{array}{c}\text { Standard } \\
\text { Deviation }\end{array}$ & $\mathrm{t}$ & Sig. & $\begin{array}{c}\text { Sig. } \\
\text { meaning }\end{array}$ \\
\hline \multirow{2}{*}{$\begin{array}{l}\text { The impact of the study suspension } \\
\text { related to the Covid-19 pandemic } \\
\text { on mathematics teaching }\end{array}$} & Urban & 43 & 3.41 & 1.139 & \multirow[b]{2}{*}{0.239} & \multirow[b]{2}{*}{0.812} & \multirow[b]{2}{*}{$\begin{array}{l}\text { Not } \\
\text { significant }\end{array}$} \\
\hline & $\begin{array}{l}\text { Migration } \\
\text { (Rural) }\end{array}$ & 15 & 3.49 & 1.074 & & & \\
\hline \multirow{2}{*}{$\begin{array}{l}\text { The role of Madrasati platform in } \\
\text { improving student learning } \\
\text { outcomes }\end{array}$} & Urban & 43 & 4.34 & .576 & \multirow[b]{2}{*}{0.519} & \multirow[b]{2}{*}{0.606} & \multirow{2}{*}{$\begin{array}{l}\text { Not } \\
\text { significant }\end{array}$} \\
\hline & $\begin{array}{l}\text { Migration } \\
\text { (Rural) }\end{array}$ & 15 & 4.43 & .526 & & & \\
\hline \multirow{2}{*}{$\begin{array}{l}\text { The role of electronic educational } \\
\text { supervision in supporting } \\
\text { mathematics teachers in Al- } \\
\text { Muzahimiyah schools }\end{array}$} & Urban & 43 & 4.33 & .542 & \multirow[b]{2}{*}{0.883} & \multirow[b]{2}{*}{0.381} & \multirow[b]{2}{*}{$\begin{array}{l}\text { Not } \\
\text { significant }\end{array}$} \\
\hline & $\begin{array}{l}\text { Migration } \\
\text { (Rural) }\end{array}$ & 15 & 4.47 & .414 & & & \\
\hline \multirow{2}{*}{$\begin{array}{l}\text { Challenges faced activating } \\
\text { Madrasati platform }\end{array}$} & Urban & 43 & 3.79 & .703 & \multirow[b]{2}{*}{0.607} & \multirow[b]{2}{*}{0.546} & \multirow{2}{*}{$\begin{array}{l}\text { Not } \\
\text { significant }\end{array}$} \\
\hline & $\begin{array}{l}\text { Migration } \\
\text { (Rural) }\end{array}$ & 15 & 3.93 & .890 & & & \\
\hline \multirow{2}{*}{$\begin{array}{l}\text { Reducing the challenges of } \\
\text { activating Madrasati platform }\end{array}$} & Urban & 43 & 4.03 & .710 & \multirow[b]{2}{*}{0.384} & \multirow[b]{2}{*}{0.703} & \multirow{2}{*}{$\begin{array}{l}\text { Not } \\
\text { significant }\end{array}$} \\
\hline & $\begin{array}{l}\text { Migration } \\
\text { (Rural) }\end{array}$ & 15 & 3.95 & .614 & & & \\
\hline
\end{tabular}

It is clear from table (11) that the t-values in the five axes were respectively $(0.239-0.519-0.883-0.607-$ $0.384)$, which is a non-significant value at a significance level less than $(0.05)$; where the significance values were, in order $(0.812-0.606-0.381-0.546-0.703)$, which are not statistically significant, which means that there are no statistically significant differences in the responses of mathematics teachers in Al Muzahimiyah Governorate to the questionnaire axes according to the variable of the school location.

Fourth: Differences according to the educational qualification variable:

Table (12) T-test for the significance of the differences in the responses of the study sample according to the educational qualification variable

\begin{tabular}{|c|c|c|c|c|c|c|c|}
\hline Axis & Qualification & $\mathrm{N}$ & $\begin{array}{c}\text { Arithmetic } \\
\text { Mean }\end{array}$ & $\begin{array}{c}\text { Standard } \\
\text { Deviation }\end{array}$ & $\mathrm{t}$ & Sig. & $\begin{array}{c}\text { Sig. } \\
\text { meaning }\end{array}$ \\
\hline \multirow{2}{*}{$\begin{array}{c}\text { The impact of the study } \\
\text { suspension related to the Covid- } \\
19 \text { pandemic on mathematics } \\
\text { teaching }\end{array}$} & Diploma & 14 & 3.23 & 1.288 & \multirow[b]{2}{*}{0.764} & \multirow[b]{2}{*}{0.448} & \multirow[b]{2}{*}{$\begin{array}{l}\text { Not } \\
\text { significant }\end{array}$} \\
\hline & BA & 44 & 3.49 & 1.061 & & & \\
\hline \multirow{2}{*}{$\begin{array}{l}\text { The role of Madrasati platform in } \\
\text { improving student learning } \\
\text { outcomes }\end{array}$} & Diploma & 14 & 4.46 & .601 & \multirow{2}{*}{0.797} & \multirow[b]{2}{*}{0.429} & \multirow{2}{*}{$\begin{array}{l}\text { Not } \\
\text { significant }\end{array}$} \\
\hline & BA & 44 & 4.33 & .550 & & & \\
\hline \multirow{2}{*}{$\begin{array}{c}\text { The role of electronic } \\
\text { educational supervision in } \\
\text { supporting mathematics teachers } \\
\text { in Al-Muzahimiyah schools }\end{array}$} & Diploma & 14 & 4.45 & .482 & \multirow[b]{2}{*}{0.722} & \multirow[b]{2}{*}{0.473} & \multirow[b]{2}{*}{$\begin{array}{l}\text { Not } \\
\text { significant }\end{array}$} \\
\hline & BA & 44 & 4.34 & .524 & & & \\
\hline \multirow{2}{*}{$\begin{array}{c}\text { Challenges faced activating } \\
\text { Madrasati platform }\end{array}$} & Diploma & 14 & 3.63 & .862 & \multirow{2}{*}{1.139} & \multirow{2}{*}{0.259} & \multirow{2}{*}{$\begin{array}{c}\text { Not } \\
\text { significant }\end{array}$} \\
\hline & $\mathrm{BA}$ & 44 & 3.89 & .710 & & & \\
\hline \multirow{2}{*}{$\begin{array}{l}\text { Reducing the challenges of } \\
\text { activating Madrasati platform }\end{array}$} & Diploma & 14 & 3.97 & .619 & \multirow{2}{*}{0.221} & \multirow{2}{*}{0.826} & \multirow{2}{*}{$\begin{array}{c}\text { Not } \\
\text { significant }\end{array}$} \\
\hline & BA & 44 & 4.02 & .708 & & & \\
\hline
\end{tabular}

It is clear from table (12) that the t-values in the five axes were respectively $(0.764-0.797-0.722-1.139-$ $0.221)$, which is a non-significant value at a significance level less than $(0.05)$; where the significance values were, respectively, (0.448 - $0.429-0.473-0.259-0.826)$, which are not statistically significant, which means that there are no statistically significant differences in the responses of mathematics teachers in Al Muzahmiyah Governorate to the axes of the questionnaire according to the variable of academic qualification.

This may be due to the fact that the suspension of studies related to the COVID-19 pandemic was surprising for everyone, and that the use of my school platform was new to teachers, students and educational supervision as well. Among the problems in which all schools, regions, teachers and students participated, including lack of technical competencies, lack of technical support, poor Internet services, lack of readiness, and the need for more time for training, time management and adaptation to the e-learning system and its tools and electronic assessment 
systems. These findings are consistent with the study (Zahara \& Kirilova, 2020), which confirmed that all schools faced the same difficulties when moving from traditional learning to e-learning as a result of the spread of the Covid-19 pandemic. The study (Rasmitadila et al., 2020) also confirmed that the pandemic COVID-19 has forced all countries to close and then move to e-learning as an alternative to traditional learning, but this process was not easy as it faced many challenges, but traditional learning solutions have become the primary and most successful option for the return of study and learning activities worldwide.

\section{Recommendations:}

1. Expansion of electronic training programs and activities for math teachers and students to use and employ the tools of the Madrasati platform in teaching mathematics.

2. Supporting and motivating the teachers financially to overcome the problem of the increasing work stress as a result of practicing digital learning activities and the teachers staying for long periods on the Internet.

3. Increase electronic educational supervision programs and activities to overcome the problems facing math teachers in employing the tools of the Madrasati platform in teaching mathematics.

4. The need for the state to take appropriate measures to improve home internet services, especially in areas of immigration.

\section{References}

Akinbadewa, B. O., \& Sofowora, O. A. (2020). The effectiveness of multimedia instructional learning packages in enhancing secondary school students' attitudes toward Biology. International Journal on Studies in Education (IJonSE), 2(2), 119-133.

Al-Harbi, S. (2021). Electronic supervision in schools in light of the Corona pandemic (Covid-19). The Virtual International Conference on Education in the Arab World: Problems and Solutions - Enriching knowledge for conferences and research. Riyadh - January 2021, pp. 310-324.

Alharthi, M. (2020). Students' attitudes toward the use of technology in online courses. International Journal of Technology in Education (IJTE), 3(1), 14-23.

Al-Husban, N.A. (2020). Critical thinking skills in asynchronous discussion forums: A case study. International Journal of Technology in Education (IJTE), 3(2), 82-91.

Al Ibrahim, M. (2020). Obstacles to using the e-learning system during the COVID-19 pandemic from the viewpoint of faculty members at Jazan University. The Virtual International Conference on the Future of Digital Education in the Arab World - Enriching Knowledge for Conferences and Research. Volume 2, pp. 124-147.

Al-Otaibi, M. (2020). The role of employing electronic platforms in developing mathematical achievement from the point of view of mathematics teachers. The Seventh Conference for Teaching and Learning Mathematics "Mathematics Education Research. Impact, Application and Practice" Distinguished research and experiences and future visions, from 20-22 Rabi' al-Akhir 1442 corresponding to 5-7 December 2020. pp. $10-45$.

Alqahtani, A. Y., \& Rajkhan, A. A. (2020). E-Learning Critical Success Factors during the COVID-19 Pandemic: A Comprehensive Analysis of E-Learning Managerial Perspectives. Education Sciences, 10(9), 216.

Al-Senussi, M.; Al-Ghamdi, A. (2021). The degree of employing the Madrasati platform in teaching to acquire oral expression skills for upper-grade students at the primary stage from the teachers' point of view. Journal of the Faculty of Education - Kafrelsheikh University - Faculty of Education, p. 100, pp. 1-50.

Arora, A. K., \& Srinivasan, R. (2020). Impact of pandemic COVID-19 on the teaching-learning process: A Study of Higher Education Teachers. Prabandhan: Indian Journal of Management, 13(4), 43-56.

Basilaia, G., \& Kvavadze, D. (2020). Transition to online education in schools during a SARS-CoV-2 coronavirus (COVID-19) pandemic in Georgia. Pedagogical Research, 5(4), 1-9.

Daniel, S. J. (2020). Education and the COVID-19 pandemic. Prospects, 1-6.

Dorn, E., Hancock, B., Sarakatsannis, J., \& Viruleg, E. (2020). COVID-19 and student learning in the United States: The hurt could last a lifetime. McKinsey \& Company.

Favale, T., Soro, F., Trevisan, M., Drago, I. and Mellia,M. (2020), "Campus traffic and e-Learning during COVID19 pandemic", Computer Networks, Vol. 176, p. 107290.

Ferdig, R. E., Baumgartner, E., Hartshorne, R., Kaplan-Rakowski, R., \& Mouza, C. (2020). Teaching, technology, and teacher education during the COVID-19 pandemic: Stories from the field. Waynesville, NC, USA: Association for the Advancement of Computing in Education (AACE).

Herliandry, L. D., Nurhasanah, N., Suban, M. E., \& Kuswanto, H. (2020). Pembelajaran Pada Masa Pandemi Covid-19. JTP - Jurnal Teknologi Pendidikan, 22(1), 65-70.

Lall, S., \& Singh, N. (2020). COVID-19: Unmasking the new face of education. International Journal of Research in Pharmaceutical Sciences, 11(SPL1), 48-53.

Mulenga, E. M., \& Marbán, J. M. (2020). Prospective teachers' online learning Mathematics activities in the age 
of COVID-19: A cluster analysis approach. EURASIA Journal of Mathematics, Science and Technology Education, 16(9), em1872.

Najm Al-Din, H. (2021). The reality of using my school platform in light of the Corona pandemic from the point of view of social studies teachers in the Kingdom of Saudi Arabia. The Virtual International Conference on Education in the Arab World: Problems and Solutions - Enriching knowledge for conferences and research. Riyadh - January 2021, pp. 205-222.

Onojah, A., \& ONOJAH, A. A. (2020). Inspiration of Technology; Effect of COVID-19 Pandemic on Education. AIJR Preprints.

Rasmitadila, A. R., Rachmadtullah, R., Samsudin, A., Syaodih, E., Nurtanto, M., \& Tambunan, A. (2020). The perceptions of primary school teachers of. online learning during the COVID-19 pandemic period: A case study in Indonesia. Journal of Ethnic and Cultural Studies 2020, 7(2), 90-109.

Rieley, J. B. (2020). Coronavirus and its impact on higher education. https://www.researchgate.net/post/Corona_Virus_and_its_impact_on_higher_education

Seage, S.J., \& Türegün, M. (2020). The effects of blended learning on STEM achievement of elementary school students. International Journal of Research in Education and Science (IJRES), 6(1), 133-140.

Song, H., Wu, J., \& Zhi, T. (2020). Results of Survey on Online Teaching for Elementary and Secondary Schools During COVID-19 Prevention and Control. ECNU Review of Education, 2096531120930021.

Toquero, C. M. (2020). Challenges and opportunities for higher education amid the COVID-19 pandemic: The Philippine context. Pedagogical Research, 5(4).

Weinhandl, R., Lavicza, Z., Hohenwarter, M. \& Schallert, S. (2020). Enhancing flipped mathematics education by utilising GeoGebra. International Journal of Education in Mathematics, Science and Technology (IJEMST), $8(1), 1-15$.

Xie, Z., \& Yang, J. (2020). Autonomous learning of elementary students at home during the COVID-19 epidemic: A case study of the second elementary school in Daxie, Ningbo, Zhejiang province, China. dx.doi.org/10.2139/ssrn.3555537

Zahra et al (2020). The Practice of Effective Classroom Management in COVID-19 Time. International Journal of Advanced Science and Technology, 29(7), 3263-3271.

Zaharah, Z., \& Kirilova, G. I. (2020). Impact of Corona Virus Outbreak Towards Teaching and Learning Activities in Indonesia. SALAM: Jurnal Sosial dan Budaya Syar-i, 7(3).

Zhao, H. (2020). Blended College English Teaching Based on Online Live Classes During the COVID-19 Epidemic Period. Journal of Contemporary Educational Research, 4(7).

Zhong, R. (2020). The coronavirus exposes education's digital divide. Retrieved from nytimes.com: https://www.nytimes.com/2020/03/17/technology/china-schools-coronavirus.html 